Diabetologia 7, 152-155(1971)

(C) by Springer-Verlag 1971

\title{
Urinary Excretion of 5-Aminolevulinate and Porphobilinogen in Diabetes
}

\author{
A. CzyzYK and A. Gregor
}

Department II of Internal Diseases, Central Clinical Hospital, Warsaw, and Institute of Haematology, Warsaw, Poland

Received: November 18, 1970, accepted: March 15, 1971

Summary. In 56 diabetics, 24 -h urinary excretion of 5 -aminolevulinic acid (ALA) and porphobilinogen (PBG) was determined by the method of Mauzerall and Granick. There was no significant difference between the mean values obtained for these patients, as compared with the control group (40 subjects). No correlation was also found between ALA and PBG excretion, as calculated against body weight, duration of diabetes and kind of treatment. There was a high degree of correlation between the excre. tion of ALA and diuresis $\left(r_{x z}=+0.75\right)$, as well as gly. cosuria $\left(r_{y z}=+0.66\right)$, whereas the correlation between the excretion of PBG and diuresis, as well as glycosuria, was low. In uncontrolled diabetes with ketonuria, (10 subjects), a significant increase in the excretion of ALA, with unchanged excretion of $\mathrm{PBG}$, was observed. - In healthy subjects, there was no significant correlation between the ALA and PBG excretion and diuresis. The determination of the urinary ALA and PBG excretion during water diuresis and during osmotic diuresis induced by intravenous infusion of hypertonic glucose solution in healthy subjects, disclosed evidence testifying against the effect of glucose on ALA reabsorption in the renal tubules. - The present findings are interpreted by the authors as resulting from enhanced ALA synthetase activity and impaired ALA dehydrase activity in uncontrolled diabetes; these disturbances being related to the defective intracellular glucose metabolism and reduced ATP production.

Excrétion urinaire du 5-aminolévulinate et du phorphobilinogène dans le diabète

Résumé. Chez 56 malades atteints de diabète, on a déterminé selon la méthode de Mauzerall et Granick l'excrétion dans les urines de $24 \mathrm{~h}$ de l'acide 5-aminolévulinique (AAL) et du porphobilinogène (PBG). On n'a pas constaté de différence marquée entre les valeurs moyennes, calculées pour ces patients, en les comparant au groupe de contrôle ( 40 personnes). On n'a pas constaté non plus de corrélation entre l'excrétion urinaire de l'AAL et de PBG avec le poids corporel, la durée du diabète et la méthode de traitement. Par contre, on a noté un degré élevé de corrélation entre l'excrétion de l'AAL et la diurèse $\left(r_{x z}=+0.75\right)$ ainsi que la glycosurie $\left(r_{y z}=+\right.$ $0.66)$. La corrélation entre l'excrétion de PBG et la diurèse et la glycosurie était au contraire faible. Dans le diabète non-contrôlé avec cétonurie (10 personnes), on a constaté un accroissement notable de l'excrétion d'AAL tandis que l'excrétion de PBG demeurait inchangée. - Chez les personnes saines il n'y avait pas de corrélation entre l'excrétion de l'AAL, aussi bien que de $\mathrm{PBG}$, et la diurèse. Los investigations sur l'excrétion urinaire de I'AAL et de $\mathrm{PBG}$ durant la diurèse hydrique et osmotique, provoquéo par la perfusion intraveineuse de solution hypertonique de glucose chez des individus sains, ont fourni des données témoignant contre l'influence du glucose sur la réabsorption de l'AAL dans les tubules rénaux. - Les auteurs interprètent ces données comme un résultat de l'accroissement de l'activité de l'AAL-synthétase et de l'inhibition de l'activité de l'AAL-déshydrase au cours du diabète non-contrôlé, à la suite du métabolisme intracellulaire perturbé du glucose et de la production diminuée de l'ATP.

Urinausscheidung von 5-Aminolaevulinsäure und Por. phobilinogen bei Diabetes mellitus

Zusammenfassung. Bei 56 Diabetikern wurde die 24 Std. Urinausscheidung von 5-Aminolaevulinsäure (ALA) und Porphobilinogen (PBG) nach der Methode von Mauzerall und Granick bestimmt. Die bei diesen Patienten erhobenen Mittelwerte zeigten keine signifikanten Unterschiede zu den Frgebnissen bei einer Vergleichsgruppe von 40 Normalpersonen. Weder für die ALA-, noch für die PBG-Ausscheidung konnte eine Korrelation zum Körpergewicht, der Diabetesdauer und der Therapieform nachgewiesen werden. Hingegen korrelierten ALA-Ausscheidung und Diurese $\left(r_{x z}=+0,75\right)$ und Glycosurie $\left(r_{y z}=+0,66\right)$ hoch, während die Korrelation zwischen PBG-Ausscheidung und Diurese, sowie Glycosurie nur locker war. Bei 10 schlecht eingestellten, azetonurischen Diabetikern wurde ein signifikanter Anstieg der ALAAusscheidung bei unveränderter PBG-Excretion beobachtet. - Bei Stoffwechselgesunden fanden sich keine signifikanten Beziehungen zwischen ALA- und PBG-Ausscheidung, sowie der Diurese. Die Bestimmung der ALAund PBG-Ausscheidung während eines Wasserstoßes und osmotischer Diurese nach i.v. Zufuhr hypertoner Glucoselösungen liefert Ergebnisse, die gegen einen Glucoseeffekt auf die ALA-Riickresorption in den Nierentubuli sprechen. - Die mitgeteilten Befunde werden von den Autoren als das Ergebnis einer verstärkten ALA-Synthetase- und verringerter ALA-Deydrase-Aktivität bei entgleistem Diabetes aufgefaßt. Diese Veränderungen werden durch die Störung des intracellulären Glucosestoffwechsels und die herabgesetzte ATP-Bildung erklärt.

Key-words: 5-aminolevulinic acid, porphobilinogen, diabetic ketosis.
In diabetes, the various stages of the intracellular glucose metabolism are disturbed, and ATP synthesis is reduced. These facts can be assumed to be reflected in the initial phases of porphyrin biosynthesis (Shemin and Russel, 1953, Shemin et al., 1955, Gibson et al., 1958, Tschudy et al. 1962, Gajdos 1967). However, no such evidence has so far been presented. In this paper, we report the results obtained for 24-h urinary ALA 
and PBG excretion in patients with diabetes, with consideration given to the various parameters of this disease.

\section{Experimental}

Urinary 5 -aminolevulinic acid and porphobilinogen were determined according to the method of Mauzerall and Granick (1956). Dowex 2 resin in the acetate form was used to separate porphobilinogen, and subsequently Dowex 50 resin in the acid form was used for the separation of 5-aminolevulinic acid. In control assays, the presence of glucose and acetone was shown not to affect the results. The subjects comprised 40 normal people and 56 diabetics. In the latter group, a total of 122 determinations of the 24-h urinary $\mathrm{ALA}$ and $\mathrm{PBG}$ excretion was carried out. Mean values and standard errors for the entire group, as well as for the different subgroups, were also calculated. In 10 patients,uncontrolled periods of diabetes and ketonuria were observed; for this group the urinary ALA and PBG excretion was calculated separately.

To estimate the effect of glycosuria on the ALA and PBG excretion, this excretion was determined in four healthy women during intense diuresis induced by water intake (water diuresis) and intravenous infusion of glucose solution (osmotic diuresis). The tested women voided urine on fasting and then drank 1.1 water during about $15 \mathrm{~min}$, whereafter urine was collected by catheterization for $2 \mathrm{~h}$. Afterwards, $1000 \mathrm{ml}$ of $20 \%$ glucose solution was administered intravenously as drip infusion for $60 \mathrm{~min}$, and urine collection was carried out for $2 \mathrm{~h}$ from the beginning of the drip in. fusion. In the two urine portions collected, ALA and PBG contents were determined; in the latter portion, glucose level was also estimated. In the course of the intravenous infusion of glucose solution, glycaemia determinations were made.

\section{Results}

Urinary ALA and PBG excretion did not differ significantly, when comparing the group of diabetics and controls. In healthy subjects, 24-h ALA excretion amounted to $0.9-3.0 \mathrm{mg}$ and in patients with controlled diabetes to $0.6-5.3 \mathrm{mg}$, thus being slightly higher; however, the difference between the means calculated for the entire groups was insignificant. In controls, 24-h PBG excretion amounted to $0.5-1.8$ $\mathrm{mg}$, and in patients with controlled diabetes to $0.3-$ $3.1 \mathrm{mg}$, thus also showing a somewhat wider range; the means of the whole groups were not, however, significantly different (Table 1).

The classification of diabetics according to body weight showed that the 24-h urinary ALA and PBG excretion was not related to the nutritional state. Likewise, the classification of patients according to the duration of diabetes, which can in some measure reflect the vascular complications of this disease, failed to indicate a correlation between the 24-h urinary ALA and PBG excretion and the duration of diabetes. Table 2 shows the classification of diabetics according to the therapy used, as tabulated against the mean values of 24-h urinary ALA and PBG excretion in each subgroup. In the subgroup of cases treated with oral drugs, eight patients took tolbutamide, five phenformin and three tolbutamide plus phenformin. Phenformin has been reported to inhibit succinic oxidase, when used in high concentrations (Wick et al. 1958); thus it was of interest to investigate whether treatment of dia-

Table 1. 24-h urinary excretion of $A L A$ and $P B G$ in normal and diabetic subjects

\begin{tabular}{lccc}
\hline $\begin{array}{l}\text { Examined } \\
\text { subjects }\end{array}$ & Number & ALA (mg) & PBG (mg) \\
\hline $\begin{array}{l}\text { Control } \\
\begin{array}{l}\text { Diabetics } \\
\text { (total) }\end{array}\end{array}$ & 40 & $2.05 \pm 0.06$ & $0.96 \pm 0.06$ \\
$\begin{array}{l}\text { Diabetics with } \\
\text { ketonuria }\end{array}$ & 10 & $2.40 \pm 0.14$ & $0.87 \pm 0.07$ \\
\hline
\end{tabular}

Table 2. 24-h urinary excretion of $A L A$ and $P B G$ as a function of the therapeutic method

\begin{tabular}{llll}
\hline $\begin{array}{l}\text { Method of } \\
\text { treatment }\end{array}$ & Number & ALA (mg) & PBG (mg) \\
\hline Oral & 16 & $2.25 \pm 0.25$ & $0.92 \pm 0.11$ \\
Insulin & & $2.00 \pm 0.28$ & $0.87 \pm 0.17$ \\
$\begin{array}{l}\text { Insulin daily } \\
\text { Insulin daily }\end{array}$ & 27 & $2.80 \pm 0.14$ & $0.87 \pm 0.07$ \\
\hline 50 U dail & &
\end{tabular}

betes with this drug affected the initial stages of porphyrin biosynthesis. The results indicated that there were no differences in the 24-h urinary ALA andPBG excretion in patients treated with phenformin, or with phenform in plus tolbutamide, compared with those taking tolbutamide only. In the former group comprising eight subjects, the mean 24-h urinary ALA excretion amounted to $2.0 \mathrm{mg}$, and $\mathrm{PBG}$ excretion to $0.97 \mathrm{mg}$, whereas in the latter group the corresponding means were 2.5 and $0.82 \mathrm{mg}$, respectively. In patients satisfactorily controlled with lower doses of insulin, the 24-h urinary ALA and PBG excretion remained within the range observed in patients treated with oral drugs. On the other hand, it is noteworthy that patients taking large doses of insulin (more than $50 \mathrm{U} / 24 \mathrm{~h}$ ) exhibited a slight enhancement of the mean urinary ALA excretion, whereas the mean urinary PBG excretion remained normal. Since an increased requirement of insulin is often observed in the uncontrolled periods of diabetes, these results could be interpreted as reflecting a correlation between the ALA excretion and control of diabetes.

This relationship is even more manifest when determining the correlation of the excretion of both por- 
phyrin precursors, as calculated against diuresis and glycosuria. The degree of correlation between 24-h urinary ALA excretion, on the one hand, and diuresis $\left(r_{x z}=+0.75\right)$, as well as glycosuria $\left(r_{y z}=+0.66\right)$, on the other hand, was high. As regards the 24-h urinary PBG excretion, this correlation was less marked (respectively $r_{x w}=+0.15$ and $r_{y w}=+0.07$ ). Consequently, the correlation between the urinary excretion of ALA and PBG in diabetics was but slight. In controls, the intensity of diuresis was not correlated with the selective urinary excretion of ALA. In this group, the coefficients of correlation between the 24-h urinary volume and 24-h urinary excretion of ALA and PBG were respectively, $r_{x z}=-0.126(p>0.05)$ and $r_{x w}=$ $+0.234(p>0.05)$. In normal subjects, the correlation between the urinary excretion of ALA and PBG was also insignificant $\left(r_{z w}=-0.099 ; p>0.05\right)$.

According to the data presented in Table 3, it is hardly probable that glycosuria itself could induce a selective increase in the urinary ALA excretion. Under the experimental conditions presented in Table 3 , in

\section{Discussion}

The present results consistently indicate that in uncontrolled diabetes the urinary excretion of ALA is enhanced, whereas that of PBG is unchanged, i.e. remains normal. These variations in the excretion of the porphyrin precursors are most accentuated in uncontrolled diabetes with coincident ketosis and ketonuria. According to the tests carried out in healthy subjects, the selective increase in the urinary ALA excretion is hardly likely to be induced only by the rise of diuresis or by the occurrence of glucose in the urine, the latter substance inhibiting the reabsorption of ALA in the renal tubules.

Since ALA synthesis is mainly related to the activity of ALA synthetase, as well as to the availability of the substrate, the explanation of the inhanced production and excretion of ALA ought to be sought within this scope. High concentrations of glucose inhibit in healthy organisms the induction of ALA synthetase by allylisopropylacetamide (AIA); however,

Table 3. Urinary excretion of $A L A$ and $P B G$ in healthy subjects during diuresis induced by water intake and infusion of hypertonic glucose solution

\begin{tabular}{|c|c|c|c|c|c|c|c|c|}
\hline Subject & $\begin{array}{l}\text { Glucosuria } \\
\text { during the } \\
\text { osmotic } \\
\text { diuresis }\end{array}$ & $\begin{array}{l}\text { Glycaemia during } \\
\text { the osmotic } \\
\text { diuresis }(\mathrm{mg} \%)\end{array}$ & $\begin{array}{l}\text { Total diu- } \\
\text { resis }(\mathrm{ml}) \\
\text { during } \\
120 \mathrm{~min}\end{array}$ & $\begin{array}{l}\text { Diuresis } \\
\mathrm{ml} / \mathrm{min}\end{array}$ & $\begin{array}{l}\text { ALA excre- } \\
\text { tion in } \mu g \text { per } \\
\text { min during } \\
120 \text { min of }\end{array}$ & $\begin{array}{l}\text { PBG excre- } \\
\text { tion in } \mu g \text { per } \\
\text { min during } \\
120 \text { min of }\end{array}$ & $\begin{array}{l}\text { Ratio of } \\
\text { change of } \\
\text { ALA excre- } \\
\text { tion to } \\
\text { change of } \\
\text { diuresis }\end{array}$ & $\begin{array}{l}\text { Ratio of } \\
\text { change of } \\
\text { PBG excre- } \\
\text { tion to } \\
\text { change of } \\
\text { diuresis }\end{array}$ \\
\hline
\end{tabular}

\begin{tabular}{|c|c|c|c|c|c|c|c|c|c|c|c|c|c|c|}
\hline & & 0 & $30^{\prime}$ & $60^{\prime}$ & w.d. & o.d. & w.d. & o.d. & w.d. & o.d. & w.d. & o.d. & & \\
\hline Ste... & $1.2 \%$ & 110 & 192 & 250 & 680 & 1650 & 5.6 & 13.7 & 1.25 & 6.25 & 5.16 & 8.58 & 2.0 & 0.7 \\
\hline Go... & $1.2 \%$ & 86 & 170 & 142 & 1200 & 610 & 10.0 & 5.0 & 5.58 & 3.58 & 6.25 & 3.16 & 1.2 & 1.0 \\
\hline Dom... & $0.6 \%$ & 84 & 300 & 184 & 360 & 1100 & 3.0 & 9.1 & 2.33 & 2.08 & - & 5.75 & 0.3 & - \\
\hline Wrze... & $0.8 \%$ & 92 & 176 & 200 & 770 & 770 & 4.5 & 6.4 & 2.08 & 1.41 & 2.83 & 4.00 & 0.48 & 1.0 \\
\hline
\end{tabular}

w.d. = water diuresis $(120 \mathrm{~min})$

o.d. = osmotic diuresis $(120 \mathrm{~min})$

the course of osmotic diuresis induced in normal subjects by intravenous infusion of glucose solution, ALA excretion, compared with the rise of diuresis, increased in one patient only, whereas it showed a marked drop in two other cases.

The highest selective increase in the urinary ALA excretion was observed in diabetics exhibiting ketonuria due to inadequate control of the disease. In the group of 56 patients under discussion, uncontrolled periods of diabetes with ketonuria occured in 10 cases. It was during just these periods that the urinary ALA excretion was markedly enhanced, whereas urinary PBG was unchanged, i.e. varied within the range observed for the remaining patients. The range of the 24-h urinary ALA excretion amounted to $1.5-6.9 \mathrm{mg}$; in five out of 10 cases, this excretion was higher than $4.0 \mathrm{mg} / 24 \mathrm{~h}$, and the mean excretion was $4.46 \mathrm{mg}$ (Table 1). This was the highest mean value of the urinary ALA excretion in the group of diabetics examined; it was significantly higher than the analogous value obtained for the entire group of diabetics $(p<0.02)$. this effect is likely to be exerted not by glucose itself, but by its phosphorylated metabolites (Tschudy et al., 1964, Marver et al., 1966). In uncontrolled diabetes, with high glucose concentrations in the extracellular spaces, glucose phosphorylation in the hepatocytes and extrahepatic tissues is markedly reduced, and ATP production decreased. Under these conditions, a rise of ALA synthetase activity and intensification of the metabolic processes in the succinate-glycine cycle are quite probable. Greater availability of glycine liberated as a result of enhanced protein catabolism (Tschudy et al., 1962) can also be involved. Under normal conditions, however, the activity of ALA dehydrase is sufficiently high to permit cyclization of even larger amounts of ALA to PBG (Tschudy et al., 1964). A selective rise of the urinary ALA excretion, with normal (and sometimes even reduced) PBG excretion, can indirectly testify to an enhancement of ALA syn. thesis and reduction of its further metabolism, and thus to a decrease in ALA dehydrase activity. 


\section{References}

Gajdos, A.: Méchanismes régulateurs de la biosynthèse normale et pathologique des porphyrines et de l'héme. Presse. méd. 75, 2103-2108 (1967).

Gibson, K.D., Laver, W.G., Neuberger, A.: Initial stages in the biosynthesis of porphyrins. 2. The formation of $\delta$-aminolevulinic acid from glycine and succinyl-coenzyme A by particles from chicken erythrocytes. Biochem. J. 70, $71-81$ (1958).

Marver, H.S., Collins, A., Tschudy, D.P., Rechigal, M. Jr.: $\delta$-aminolevulinic synthetase. II. Induction in rat liver, J. biol. Chem. 241, 4323-4329 (1966).

Mauzerall, G., Granick, S.: The occurrence and determination of $\delta$-aminolevulinic acid and porphobilinogen in urine. J. biol. Chem. 219, 435-446 (1956).

Shemin, D., Russell, C.S.: $\delta$-aminolevulinic acid, its role in the biosynthesis of porphyrins and purines. J. Amer. chem. Soc. 75, 4873-4874 (1953.)
- Abramsky, T.: The succinate-glycine cycle. I. The mechanism of pyrole synthesis. J. biol. Chem. 215, $613-626(1955)$.

Tschudy, D.P., Rose, J., Hellman, E., Collins, A., Rechigal, M. Jr.: Biochemical studies of experimental porphyria. Metabolism 11, 1287-1301 (1962).

-Welland, F.H., Collins, A., Hunter Jr., G.: The effect of carbohydrate feeding on the induction of $\delta$-aminolevulinic acid synthetase. Metabolism 13, 396-406 (1964).

Wick, A.N., Larson, E.R., Serif, G.S.: Site of action of phenethylbiguanide, a hypoglycemic compound. J. biol. Chem. 233, 296-298 (1958).

Dr. A. Czyzyk

Dept. III of Internal Diseases

Medical Academy

ul. Lindleya 4

Warsaw, Poland 